\title{
The Use of Genre-Based Approach to Teach Students Writing Skill of Hortatory Exposition Text in Bahasa Indonesia
}

\author{
Asep Nurjamin, Lucky R. Nurjamin \\ Sekolah Tinggi Keguruan dan Pendidikan (STKIP) Garut, Indonesia
}

\begin{abstract}
Nowadays, genre-based approach (GBA) has become a popular approach in teaching English, particularly in writing. The interest to use this approach in other languages emerges following its success in English language teaching. However, in fact, the use of this approach in teaching other languages, in this case Bahasa Indonesia, is still limited. Thus, a study to observe the use of genre-based approach in teaching Bahasa Indonesia is necessary. This study aims to investigate the impacts of genre based approach to teach writing hortatory exposition text in Bahasa Indonesia. Both quantitative and qualitative in form of case study was employed to gain the data. The data were taken from observation, tests, and interview involving six students in senior high school level. As result, genre-based approach gives significant impacts on the students' writing of discussion text, particularly in the genre moves; schematic structure and linguistic features of the text.
\end{abstract}

Keywords: Genre-based approach, Bahasa Indonesia, hortatory exposition text, students' writing skill

\section{INTRODUCTION}

Genre-based approach (GBA) is the latest suggested approach applied in the newest Indonesian curriculum (Emilia, 2011). It is in line with the focus of curriculum target which emphasizes genre as the basic material for language teaching. Moreover, the goal of GBA is that students are able to do communication based on particular purposes by considering the characteristic of linguistic features and the organisation of the text.

Moreover, in every quoted definition, GBA is known as an approach consisting of four steps. They are; Building Knowledge of Field, Modelling of The Text, Joint Construction of The Text, and Independent Construction of The Text (Martin, 2003; Emilia, 2011). First, in building knowledge of field, teachers scaffold students to have strong background knowledge of the topic (Gibbons, 2002). This step aims at building students capacity in understanding the cultural context of culture and social purpose of the genre (Derewianka $\&$ Jones, 2012). Second, modelling of the text is a step whose focus is on developing students' knowledge of the language and how it works (Derewianka \& Jones, 2012). Moreover, this stage also facilitates students to write genre by being familiar with the purpose and the feature of the text (Dderewianka, 1997). As the third stage, joint construction of the text provides students chance to firstly implement their understanding on the text through constructing a particular text in group (Emilia,
2011). This step may be applied in two activities: scribing (the whole class group) or by a small group (Derewianka, 2011; Emilia, 2011). The last stage, independent construction of the text, is a phase when students attempt to construct the text by themselves. This involves the process of drafting, writing, revising, and publishing (Derewianka \& Jones, 2012).

Numerous studies related to the use of GBA have been conducted. One of them was done by Fajriah (2015). She examined the effectiveness of GBA in teaching exposisition genre to EFL second grade students in one of state senior high schools in Garut. This study shows that GBA is effective to teach spoken hortatory genre. Additionally, Syarifah (2016) also undertook similar study which investigated the use of scaffolding in GBA to teach written discussion text in EFL tertiary level. The result shows that GBA is effective to accomodate the use of scaffolding in teaching genre, particularly discussion text.

However, this approach has not been commonly applied in teaching Bahasa Indonesia. Many teachers teach genre without systematic steps, which often lead students to get confused in terms of the function of the genre itself in their real communication (Fajriah, 2015). Therefore, from the explanation above, it is necessary to extend the study of GBA in other context especially in Bahasa Indonesia context either as the first language or second language for Indonesian students. This study is also needed to be taken into account since the study of GBA in teaching Bahasa Indonesia is still limited.

Therefore this present study aimed at examining the effectiveness of GBA in teaching Bahasa Indonesia in the genre of hortatory exposition in a state senior high school in Garut and investigating the extent this approach develops students' capacity in writing hortatory exposition. This genre was chosen since it is assumed as one of chalenging types of text which requires students' critical thinking. Moreover, the topic discussed in this genre is about "the controversial issue of the increase of cigarette price in Indonesia".

\section{METHODS}

Both quantitative and qualitative approaches in the form of case study were employed to gain the data. More specifically, quasi-experimental design was used to examine whether or not GBA is effective to teach hortatory exposition in Bahasa Indonesia. Additionally, a case study was chosen to 
investigate the improvement resulted from GBA in students' hortatory exposition. This study is categorized as a case study since the study took place in natural setting (Creswell, 2010), the data were analyzed in descriptive approach (Grimes \& Shchulz, 2002), and the study was conducted in a small case (Bogdan \& Biklen, 1992).

In this study, there were 40 students who served as the sample. Moreover, there were six students serving as the focus participants which were purposively selected based on the level of achievement in the pre-test result.

To collect the data, observation, tests and semi structured interview were undertaken in this study. In the observation, the data were collected through field-note and observation checklist in which the researcher acted as participant-observer. Additionally, the tests were done twice; pre-test and post test. In the tests, students were asked to construct a written hortatory exposition essay in Bahasa Indonesia with the theme of 'the issue of the significant increase of cigarrette price in Indonesia'. Semi-structured interview was undertaken to support the findings gained from the students' text.

Moreover, the data in this study were analyzed using dependent t-test (SPSS) and genre analysis as adapted from Butt, Fahey, Feez, Spinks, and Yallop (2000), and Emilia (2011). Dependent t-test functioned to examine the effectivenesss of GBA statistically; meanwhile, genre analysis functioned to analyze the improvement of students in writing a hortatory exposition in three aspects; social function, text organization, and lexicogrammatical features of the text.

\section{FINDING AND DISCUSSION}

a. The effectiveness of Genre Based Approach in Teaching Students' Writing of Hortatory Exposition in Bahasa Indonesia

As the first findings, the data gained in this study show that GBA is effective to be used in teaching students' written text of hortatory esposition in Bahasa Indonesia. It is in line with the result of the statistical calculation using t-test formula. Below is the visualization of the data showing that GBA is effective to teach students' writing of hortatory exposition in Bahasa Indonesia.

Table I. Paired Samples Statistics

\begin{tabular}{|c|c|c|c|c|c|}
\hline & & Mean & $\mathrm{N}$ & $\begin{array}{l}\text { Std. } \\
\text { Deviation }\end{array}$ & Std. Error Mean \\
\hline \multirow{2}{*}{$\begin{array}{l}\text { Pail } \\
1\end{array}$} & Pretest & 71.2375 & 40 & 4.88192 & .77190 \\
\hline & Posttest & 79.5875 & 40 & 5.33360 & .84332 \\
\hline
\end{tabular}

Table II. Paired Samples Test

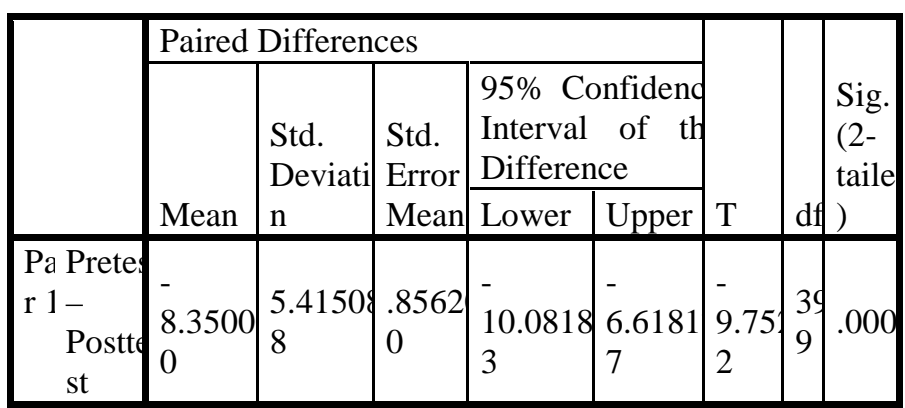

From the tables above, it is shown that the values of pre-test and post test are different. Specifically, the result shows that $\Sigma_{o} \quad=-9.752$ is lower than the critical value meaning that it lies out of the accepted area of $H_{0}$; therefore, $H_{0}$ is rejected and $H_{\mathrm{a}}$ is accepted. By this, it can be concluded that there is a difference in terms of the students' witing performance between the students' pre-test and their post-test score. Therefore, this hypothesis testing shows that genrebased approach is effective to be applied in teaching written hortatory exposition in Bahasa Indonesia.

b. The Improvement of Students' Written Text of Hortatory Exposition in Bahasa Indonesia

There are three major points of the improvement of the genre moves as reflected in the students' writing of hortatory exposition in this study; they are, social function of the text, generic structure and linguistic features of the text.

\section{i. Social Function}

In this point, the data show that students generally improve their abilities in achieving the social function of the texts. As an example, one of low achievers (AD) was able to consistently persuade readers to support the idea of the increase of cigarrette price. It is very different from his previous text produced in the pre-test in which he still explains the dissadvantage of increasing the price of cigarrette leading him to get an inconsistency in delivering the ideas. Another improvement is also reflected in TS (a middle achiever) in which she wrote some elaborations in strenghtening her arguments to make readers sure that the increase of cigarrette is not effective way to do. It is also different from her previous text in which she only put very a short argument without any elaboration; I think increasing the price of cigarette in Indonesia is not good because it may become a threat to the country's economy. In other words, students are able to achieve the social function of hortatory exposition; that is, to persuade readers to do something (Knapp \& Watkins, 2005; Gerot \& Wignel (1994).

\section{ii. Generic Structure}

In terms of generic structure, all students were able to organize their texts using appropriate structure of the text; thesis statement, arguments, and recommendation. This improvement is obviously different from students' texts produced in the pre-test. For instance, BP (a low achiever) did not write a thesis statement in his pre-test, he directly wrote a short argument followed by short suggestion; In my opinion, the price of cigarette must be increased because smoking is 
very dangerous. So, let's support the government to increase the price of cigarette.. However, in his post-test, he could organize his text starting from giving a current issue of the increase of cigarrette, a thesis statement, two strong arguments and closed it by a recommendation. Another improvement is also shown by YT (a middle achiever) who could write clear suggestion at the end of her writing; thus, as a good citizen, we should support the government's effort in increasing the price of cigarette. . This is different from her text in the pre-test in which she only concluded her arguments; thus, the idea of increasing the price of cigarette is positive. In conclusion, the students were succesful to organize the hortatory exposition text in Bahasa Indonesia including thesis statement, arguments, and recommendation (Gerot \& Wignel, 1994; Derewianka, 1997; Emilia, 2011).

\section{iii. Linguistic Features}

In terms of linguistic features, most students improve their capacities in involving the role of linguistic features of hortatory exposition into their texts in the post test. as an example, AK (a high achiever) could write a passive voice in her final text which was absent in her first text. It shows that she understood that passive voice is one of characteristics of hortatory exposition. In addition, YT (a middle achiever) put some technical terms of 'smoking' in her final text (tembakau, nikotin, kanker). It is different from the text in the pretest in which she only used the words smoking and cigarrette as the technical terms. Another improvement is also reflected in the text of KS (a high achiever) in which he put expert's opinions in his final text (it is in line with Soerojo (2015) in a workshop on effective control on cigarette consumption who argued that in Jokowi's era he is pessimistic about the president's commitment in decreasing the number of smokers). KS also put some evaluating statements in his final text (e.g. increasing cigarette price is not an effective solution), and impersonal statements (e.g. due to their addiction, it would not prevent smoker to buy cigarette).

Those findings above reflect that students are able to fulfill the lexicogrammatical features of hortatory exposition: technical terms, passive voice, impersonal statement, evaluating statement, general nouns, connectives, mental verbs, and expert opinions (see Butt, Fahey, Feez, Spinks \& Yallop, 2000; Emilia, 2011).

As additional findings gained from the interview, students generally perceive the use of GBA positively in their writing process of hortatory exposition in Bahasa Indonesia. For example, BP said that "melalui pendekatan ini, saya menjadi paham mengenai apa saja yang harus saya tulis, sebelumnya saya selalu stuck dalam menentukan ide penulisan”. Another response was expressed by a middle achiever (YT) stating that Joint Construction of the Text helped her to share her understanding of the text with her peers as she said; "saya sangat terkesan ketika belajar menuliskan eksposisi hortatori dalam kelompok karena saya dapat saling tukar pikiran, dan ide dengan kelompok". This statement is in line with the essence of JCoT in GBA as stated by Hyland (2004) and Feez (1998a).

\section{CONCLUSION}

In conclusion, this study reveals that genre-based approach is considered as an effective approach in teaching writing, particularly hortatory exposisiton text in Bahasa Indonesia. This has been proved by the improvement of the focus-participant writing ability involving ability in understanding the social function, the generic structure, and the linguistic features of the text.

\section{REFERENCES}

Bogdan, R. \& Biklen S.K. (1992). Qualitative Research for Educational Transmissions. London: Routledge.

Butt, D., Fahey, R., Feez, S., Spinks, S., and Yallop, C. (2000). Using Functional Grammar; An Explorer's Guide. Sydney: National Center for English Language Teaching and Research, Macquarie University.

Derewianka, B. (1997). Exploring How Text Works. Sydney: Primary English Teaching Association.

Derewianka and Jones (2012). Teaching Language in Context. Melbourne: Oxford University Press.

Emilia, Emi (2011). Pendekatan Genre-based Approach dalam Pengajaran Bahasa Inggris: Petunjuk Bagi Guru. Bandung: Rizqi Press.

Fajriah, Yustika N. (2015). Comprehensible Input, Explicit Teaching, and Corrective Feedback in Genre-Based Approach to Teaching Hortatory Exposition. Thesis. Indonesia University of Education.

Feez, S. (1998a). Text-based Syllabus Design. Sydney: National Centre for English Language Teaching and Research.

Gerot, L. \& Wignel, P. (1994). Making Sense of Functional Grammar. Sydney: Gerd Stabler.

Gibbons, P. (2002). Scaffolding Language, Language Learning: Teaching Language Learners in The Mainstream Classroom. Portsmouth, USA: Heinneman.

Grimes, D. A. \& Shchulz, K. F. (2002). Descriptive studies: What They Can and Cannot Do. Lancet Vol.359. [online] Retrieved on http://www.lancet.com [08/08/12]

Harmer, J. (2007a). The Practice of English Language Teaching. Malaysia: Pearson Education.

Hyland, K. (2004). Genre and Second Language Writing. Ann Arbor: University of Michigan Press.

Knapp, P. \& Watkins, M. (2005). Genre, Text, and Grammar. Sydney: UNSW Press Book.

Syarifah, Eva (2016). Scaffolding in The Teaching of Writing Discussion Text Based on SFL-GBA. Thesis. Indonesia University of Education. 